\title{
Pupils' and Parents' Perspectives Towards Using Smartphone Strategies to Improve Reading Skills
}

\author{
Suher Sulaiman \\ Faculty of Education, Universiti Kebangsaan Malaysia, 43600 Bangi, Selangor, Malaysia \\ Maslawati Mohamad \\ Faculty of Education, Universiti Kebangsaan Malaysia, 43600 Bangi, Selangor, Malaysia \\ Azlin Norhaini Mansor \\ Faculty of Education, Universiti Kebangsaan Malaysia, 43600 Bangi, Selangor, Malaysia \\ Bity Salwana Alias \\ Faculty of Education, Universiti Kebangsaan Malaysia, 43600 Bangi, Selangor, Malaysia \\ Azlina Abdul Aziz \\ Faculty of Education, Universiti Kebangsaan Malaysia, 43600 Bangi, Selangor, Malaysia
}

\begin{abstract}
In this 21st century, reading skill is one of the most essential skills to achieve language literacy. On this basis, an early introduction to proper reading strategies shall develop good attitudes towards reading. Based on a study conducted by the Malaysia National Library in 2015, the rate of reading is lower among Malaysians, with only 15 to 20 books on average per year. Due to this, the researchers conducted a reading workshop, "Using Smartphone to Improve English Skills" in three districts in three different states. This qualitative study was embarked to explore the perception of workshop participants (pupils and parents) towards the reading workshop. Despite the pupils' and parents' perceptions towards the workshop which generally are positive, however, some suggestions are given to further improve the reading workshop. The participants in this study consisted of 79 people of different ages, races and socioeconomic statuses. The pupils are from primary schools with the ages of 10 to 12 years old (Year 4 to Year 6) and the parents are from the ages of 25 to 50 years old. They are residents of the Southern region of Malaysia which are Negeri Sembilan, Melaka and Johor. The research instruments employed were field notes, open-ended interview responses from Google Form and semi-structured interview responses. The findings suggested that the majority of the students and parents agreed that the various reading strategies introduced using smartphones are both interesting and exciting and may serve as the focus of future studies. The study implies that the smartphone reading strategy workshops should be carried out at different locations to enhance the pupils' reading skills in reading English materials. Both parents and their children should participate in this workshop to ensure the strategies could be practiced effectively at home.
\end{abstract}

Index Terms - primary school, reading strategy, 21st century learning, mobile learning

\section{INTRODUCTION}

In this 21st-century learning environment, it is imperative for parents, pupils, and the community to work collaboratively to encourage literacy via the internet. This change should be embraced as it is common across the globe (Fajri et al., 2020). In relation to this, collective efforts are required to change students' attitudes, thus, ensuring they comprehend English materials more effectively. Learning in the 21 st century is no longer new to the community. Erdoğan, (2019) indicated that the $21^{\text {st }}$ Century Skills alliance showcases four learning and innovation skills known as the 4Cs of communication, teamwork, imagination, and critical thinking. In the context of reading, the early adoption of reading habits with parents' assistance must be established. The parents and community play significant roles to ensure that children are encouraged to read as much as possible particularly in the context of Malaysia. The study conducted by the Malaysia National Library in 2015 showed that Malaysians on average read about 15 to 20 books per year. In developed countries, however, people read an average of 40 books per year (Meikeng, 2019). This figure indicates a wide gap in reading interest among Malaysians and the citizens of other developed countries. Malaysia received a score of 415 in reading literacy in the Program for International Students Assessments (PISA) scale as reported by the Organization for Economic Cooperation and Development (OECD) in 2018 (Chin, 2019). Despite having a long way to go as Malaysia's score is below average (average global score: 487), the local government has put conscious efforts in order to achieve the targeted literacy rate which includes primary school children to have a strong grasp of literacy at home. 
Many studies indicate that effective parent-child communication is vital to ensure the children's education performance (Brown et al., 2019). Parents play a key role in introducing reading as a family activity. To ensure its effectiveness, teachers especially primary school teachers are also required to plan and organize lessons as well as create resources that focused on developing 21st-century learning skills. According to Gerald (2015), the teaching and learning process centered on the $4 \mathrm{Cs}$ is aimed to give all pupils equal opportunities on the stage of the learning hub as the reading strategies employed by the good and poor language learners differ. There are two groups of language learners; those who are skilled and unskilled (Ling \& Hamidah, 2020). Since many studies indicate that teaching reading strategies at primary schools could enhance reading skills, the researchers conducted a reading strategy workshop using smartphones focusing on primary school students. Their parents were also invited to attend the workshop in an attempt to introduce 21st-century reading tools in their learning (Li \& Qiu, 2018). Together with their parent/s' assistance, the reading workshop is aimed to help increase the children's interest in reading English materials. Additionally, the pupils could discover the effectiveness of the activities and strategies that have been taught throughout the workshop and eventually develop lifelong reading habits (Rajaram, 2021). Therefore, the researchers carried out this study in order to identify the pupils' and parents' perceptions towards the reading strategy using smartphone workshop and their suggestions to improve the workshop.

\section{LITERATURE REVIEW}

Reading is a complex cognitive activity. Therefore, reading is described in various ways by many scholars. In the past, some scholars regarded it as a cognitive process. Others argue that reading is an attempt to interpret printed symbols. According to others, the process of comprehending written language is what learning is all about (PurcellGates, 2020). Despite continuing disagreement over the specific mechanisms of reading, there are a few broad concepts that most scholars agree on. Reading for fun enables pupils to improve their reading skills. Reading also increases their vocabulary repertoire, general knowledge, and their views on other cultures (Bartik \& Hershbein, 2018). In order to learn to read, children must attend to words, decode and interpret the written words on the page. New vocabularies and enhanced comprehension are of paramount importance as the children begin to read on their own. From the Theory of Cognitive Constructivism (Piaget, 1968), humans are unable to grasp and apply the knowledge that is instantly delivered to them. Instead, they must relate the new knowledge with their existing knowledge. They develop their reading skills as a result of gaining new real-world experience. Schemas are mental representations of the world that people develop as a result of their experiences. Two complementary processes, assimilation and accommodation, alter, expand, and refine these schemas.

Skills for the 21st century include collaboration, communication, creativity, and critical thinking. Primary and secondary school children must make the transition from learning to read to reading for learning because this is essential for their future success (Mo-Bjørkelund, 2020). Petscher et al. (2020) insist readers of adolescent age must be able to deal with increasingly difficult texts. This is important to learn more about the subjects they are studying. A student's ability to grasp the complex subject matter in higher grades is built on his or her ability to read proficiently. Students must be able to read English materials since primary school before they could master the 4 Cs: critical thinking, collaboration, creativity, and communication (Erdogan, 2019) skills. Without the ability to read effectively, pupils in primary and secondary school fall further behind their peers and are more likely to drop out before they complete their secondary school learning. Teachers must have access to a complete English language curriculum that integrates teacher-led and online learning in a blended learning environment, as well as continuing assessments, data analytics, and literacy assistance for teachers if they want to be efficient teachers (Pellegrino, 2017). In addition, according to Luka and Seniut (2019), by being able to read and understand more difficult texts, students will be able to produce better-written assignments as their reading skills improve. Immediate and positive feedback encourages students to improve their reading skills especially in reading English materials.

Reading strategy is a strategy that enables a reader to effectively interpret print materials to derive meaning. Singh, Ying and Muniandy (2021) proposed that to help improve pupils' reading comprehension and decoding skills, reading strategies that enhance students' reading capabilities are necessary to be taught for all pupils as classroom activities or reading workshops, particularly for struggling readers. Many studies indicate that there has been substantial progress in developing primary school pupils' reading strategies in the last two decades. Based on the pieces of evidence compiled by Erdogan (2019), pupils who can understand and use many words are better readers. These pupils could also develop their interest in reading and writing. Teachers' creativity is very essential to spark pupils' interest in reading. Teachers are obligated to conduct various reading activities, reading workshops, and produce materials that promote $21^{\text {st }}$-century skills (Anstey \& Bull, 2018). In this era, primarily marked by the rapid evolution of technology, globalization, and the rising demand for creativity, equipping pupils with reading strategies using smartphones is one of the advancements needed to improve their reading skills (Intr \& Ajaj, 2021).

Parental involvement is pivotal in assisting their children in reading (Gay et al., 2020). Samsuddin et al. (2019), added that young children should be exposed to parental reading. The findings of the study published by Lundstrom (2017), denoted that in order for students to be successful academically, parents should support and assist their children in becoming interested in reading and further develop their reading skills. As supported by Brown et al. (2019), effective parenting with regards to teaching children to read resulted in greater intellectual stimulation, better self- 
concept, and aspirations for good education. It is difficult for these students to become good readers without direct interventions and frequent practices at home (Behtash, Barabadi \& Eskandari, 2019).

The power of motivation plays a critical role in promoting reading (Tanaka, 2017). A major drive in achieving reading goals is motivation, which involves initiating, guiding, and maintaining goal-oriented behavior (Ushioda \& Dörnyei, 2017). Human actions are propelled by motivation (Talmi, Hazzan \& Katz, 2018). Teachers can encourage students to evaluate their cognitive processes by prompting them to scrutinize their thought processes (Duff, 2017). Developing positive mental models for how we learn, as well as our capacity and limits, are equally important.

An application that runs on iPhones, tablets, and other mobile devices is referred to as a mobile app (Masrom et al. 2016). These apps can be downloaded using smartphones. Some apps are free and others need to be subscribed to. With portable and accessible mobile devices, learning and reading materials are readily available. Parents do not have to spend much money on their children's reading activities as the apps suggested in this reading workshop conducted by the researchers are free. In language learning environments, mobile learning has been shown to optimize the potential of mobile devices as teaching instruments (Daud et al., 2015). Due to the rapid global growth of mobile technology, mobile learning is becoming increasingly popular and widespread in Malaysia. Kung-Teck et al., (2020) show that incorporating mobile learning into teaching instruction is highly useful, as it promotes interactive learning via Grammarly, e-dictionary, e-book, YouTube, Quizizz and MindMap via mobile devices. The use of mobile technology in education, sometimes known as "mobile learning," has piqued academics' curiosity to date. As the younger population becomes more tech-savvy, a rising body of literature has noted that mobile learning is becoming more popular and respected. Therefore, the researchers designed and carried out a half-day reading workshop using smartphones for primary school pupils.

Ismail et al. (2016) conclude that the increasing use of mobile devices by the present generation of students is one of the driving causes behind the implementation of mobile learning in educational institutions. Perrin and Duggan (2015) also remind that young pupils, particularly those between the ages of 10 and 18, have a favorable opinion of online games. For many years, teachers have wanted to increase their students' English proficiency levels by integrating mobile devices in classroom activities (Hashim et al., 2017; Govindasamy et al., 2019; Hasin \& Nasir, 2021). As outlined in the Malaysia Education Blueprint (MEB), the Malaysian government encourages wider adoption and diffusion of information and communications technology (ICT) in education (MEB 2013-2025 (Ganapathy, 2016), reshaping education to be future-proof in line with the industrial revolution is part of MEB 10-year strategy. Niko Sudibjo et al.'s (2019) study is on utilizing smartphones to teach reading. According to them, mobile reading applications are appropriate and user-friendly for both individuals and group reading activities. The following is a list of mobile applications used in the reading workshop conducted by the researchers:

1. Online Dictionary

2. Visual Dictionary Online

3. Google Lens and Google Translator

4. Grammarly

5. Magic Keys Children's Story Book

6. www.kidsworldfun.com/ebooks.php

7. You Tube Story Watching

\section{METHODOLOGY}

\section{A. Research Design, Research Procedure and Research Instruments}

The research design for the undertaken study is a qualitative method in which the researchers gathered answers for the research questions through interview responses, field notes and open-ended responses via a Google form. Multiple case studies were employed since three research sites were used to collect the data for specific purposes (Yin, 2018). The primary research instrument in this study is semi-structured interviews. To triangulate the findings, the researchers used field notes and responses from open-ended responses via Google Form. The researchers wrote field notes of their observations and feelings throughout the reading workshop. The interviews were used to find out the participants' perceptions towards the activities conducted reading workshop and their impacts on the pupils' reading skills. The researchers conducted 15-30 minute interview sessions per family. The researchers approached each family who attended the workshop. Each family was asked similar questions. They responded honestly, and the interview responses were recorded via the MP4 player.

After the interviews, the researchers prepared the transcripts verbatim and asked the participants to counter-check the transcripts to make sure the transcripts are accurately transcribed and interpreted. The participants were interviewed in the Malay language as it is the national language. Some parents are not able to speak in English well thus they faced difficulties to express themselves in English. After that, the researchers translate the interview responses into English. Time constraints resulted in the researchers only asking a limited number of interview questions. A questionnaire consisting of open-ended items via Google form was employed as a part of data enhancement and for triangulation purposes. The questionnaire consists of 30 statements with a 3-point Likert scale response, ranging from disagreeing to strongly agree, to indicate their level of agreement to various statements. In order to ensure the consistency of the collected data, the questions on the Google Form are similar to the interview questions. The data were automatically 
collected in the clouds and analysed. A Google Form was given to the participants (25 parents) so that they could complete the data collection process. In addition, data analysis could be generated automatically using the features in the Google Form. The data from the Google Form and semi-structured interviews are able to provide answers to the research objectives: to identify the pupils' and parents' perceptions towards the reading workshop and identify their suggestions to improve the reading workshop.

\section{B. Setting}

The participants were required to attend a 3-hour reading workshop using smartphones on the sites. During the workshop, they were introduced to some apps and needed to use the apps with their family members. After the reading workshop, they needed to answer some interview questions. During the semi-structured interview session, they were asked to give their perceptions of the workshop and give suggestions to improve the reading workshop. After 2 or 3 weeks, parents were given a Google Form with similar questions to confirm their suggestions mentioned during the interviews (Cohen et al., 2007). Consent forms were given to them to be signed and collected upon participants' arrival at the workshop. The observations enabled the researchers to uncover unnoticed aspects of a subject and gain access to perspectives that the participants might not openly express in the interview session (Driscoll, 2011).

\section{Participants}

The participants of this study were 79 people aged between 10 - 55 years. An age range of 25 to 55 applies to the parents, and 10 to 12 years applies to the children (primary school). Both parties, namely the parents and their children participated in the interactive workshop. The participants were from the southwest coast of Malaysia. Three districts involved were namely Port Dickson, Negeri Sembilan, Segamat, Johor and Jasin, Melaka. They were selected as the schools in this district volunteered to participate in the reading workshop. The participants were labeled as P for parents and PP for pupils. Pseudonyms were given to the participants to ensure confidentiality. This is to adhere to research ethics.

\section{Workshop Structure}

According to Royer (1987), the success for the long-term growth of any nation's education system is the development of high-quality reading workshops. Designing such workshops is a challenge because reading is a skill that must be taught directly. The workshop structure for these reading strategies was carefully designed to ensure the impact on the participants was optimal and positive. The researchers planned the reading workshop together with the schools involved, then it was submitted to get approval from the school authorities. After that, the workshop was advertised on social media such as Facebook and Instagram to the nearby schools. An invitation letter was also distributed to the nearby primary schools for the pupils to participate in the workshop. There are no registration fees charged. The workshop was a walk-in entry. The workshop was held in one and a half hours. After the workshop, the participants were gathered in groups and interviewed by the researchers. A week or two was given to them to practice the strategies at home and after that open-ended responses via a Google form were distributed to them in WhatsApp. Three Whatsapp groups were created. The interview responses were transcribed and analysed.

\section{FINDINGS}

The findings are to provide the answers to two research questions:

i) What are the pupils' and parents' perceptions towards the reading strategies taught in the workshop?

ii) What are the participants' suggestions to improve the workshop?

Three research instruments were employed and they were given abbreviations. For example, the semi-structured interview is labeled as (INT), field notes (FN), and open-ended responses via Google Form (GF).

i)Research Question 1

What are the pupils' and parents' perceptions towards the reading strategies taught in the workshop?

Positive Perception

During the workshop, observations were carefully conducted by the researchers and recorded in the field notes starting with the first workshop in Port Dickson and ending in Jasin. The researchers' field notes indicate the participants' positive reactions when they arrived and while they were participating in the workshop. Their smiles, involvement, and concentration revealed a high sense of excitement as the participants were eager to be involved in the activities organized. Both parties, parents and their children were engrossed in using the taught apps during the activities. The researchers were there to guide the participants if they face any difficulties or they asked any questions. The interview responses also indicate the participants' excitement. The family members sat next to each other and started using Google Lens with excitement because they have never tried the apps before. They were happy to know that the application taught could be used to translate the targeted language within a few seconds. On the same note, despite some parents being lost trying to figure out the usage of the online dictionaries at the initial part of the workshop, the parents convinced their children to keep on trying until he/she succeeded in finding the meaning, pronunciation, word categories and how to apply the words in sentences. They were lost because they had never used the apps taught previously. Some parents had problems with the internet connection. Some internet providers were not good at that time, 
thus, slowing down the process of retrieving and installing the websites/apps. The field notes record indicates that the participants helped each other while participating in the activities together. Parents tried to help their children to improve their reading ability. Brown et al.'s (2019) believe that the parents' role is important in actively engaging with their children reading process. They further added that parents' involvement and encouragement resulted in their children's positive effort and attitude towards learning. Surprisingly, similar scenarios were observed at all the sites that the reading workshops were conducted. The field notes confirmed the participants' confessions during the interview sessions and open-ended questions via Google Form.

"We used to buy books in our time. We make notes. Now we could just use the smartphone. The children love it. We have to get used to it. Internet, Google. If we don't know how to use it, we cannot teach our children about the apps. They sometimes teach us how to use the smartphone. In fact, they are good at this." (INT, JHR, P7)

"Parents were also mesmerized by the apps introduced and eager to help their children in exploring the apps." (FN, NSN, $10 \mathrm{am}$ )

"The family seemed to enjoy the session and we could see their efforts to help each other." (FN, NSN, 11 am)

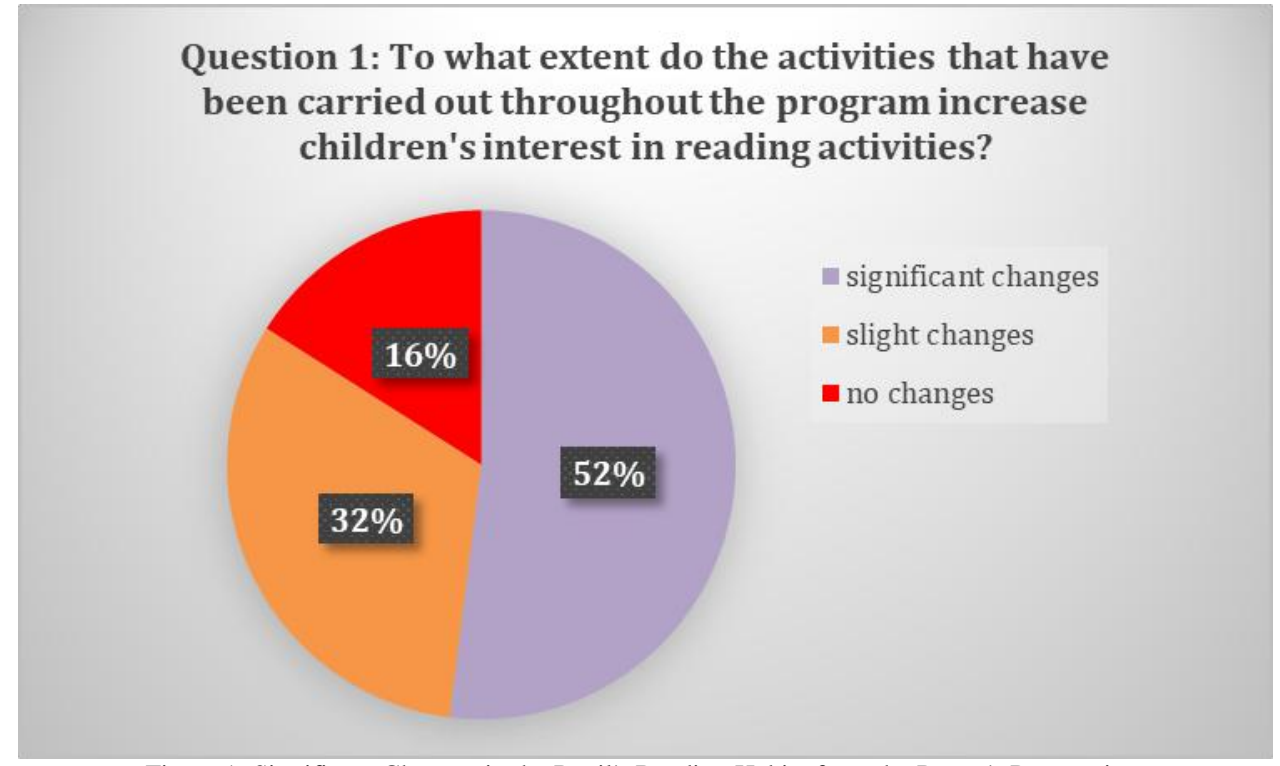

Figure 1: Significant Changes in the Pupil's Reading Habits from the Parent's Perspective.

Based on Research Question 1, from 25 parents' responses, 4 (16\%) of the participants confirmed that there are no significant changes in their children's reading habits, $8(32 \%)$ of them admitted that there are slight changes in their children's reading habits and $13(52 \%)$ of them agreed there are huge changes in their children's reading habits.

The findings of this study support Swift's (1993) claim that pupils who are encouraged to believe in themselves and their abilities developed positive attitudes towards reading and boost their self-confidence. The pupils noted that there is a significant change of interest in reading which is in line with the parents' opinion based on their answers in the Google Form. This statement is derived from the interview responses and open-ended responses via Google Form as in Figure 2:

"I can understand more about the gadget and use the English Language more fluently" (INT, MLK, PP5)

"The lessons (applications) are all already in the smartphone" (INT, JHR, PP9)

Nevertheless, a small number of participants ( 3 of them) reported that they felt indifferent in regards to their interest in reading activities, this was concluded with Chin's (2019) opinion about reading habits for Malaysians. According to Chin, Malaysia received a score of 415 in reading literacy in the Program for International Students Assessments (PISA) indicates that Malaysians do not have reading as their habit like other developing countries. The details of the responses are displayed in Figure 2. 


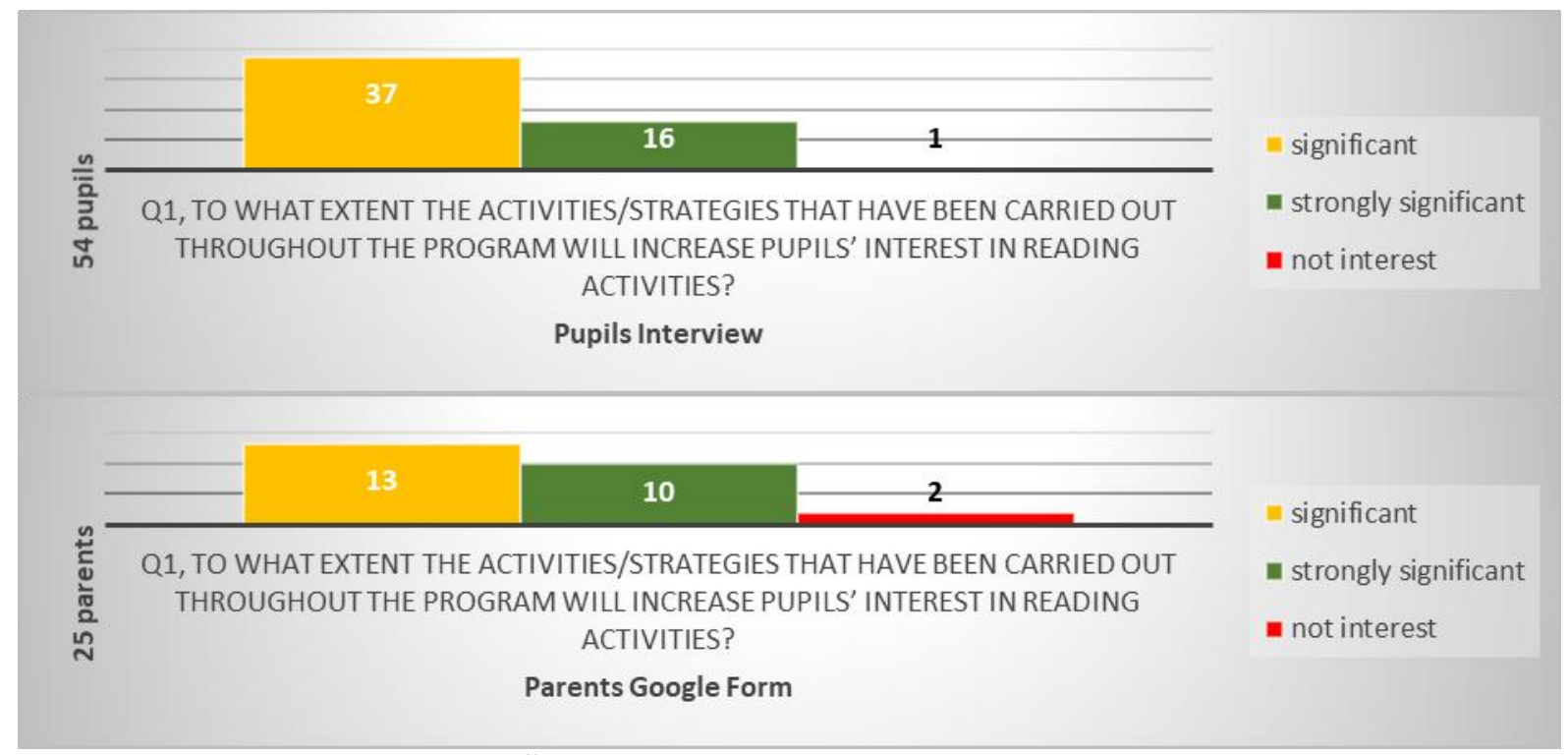

Figure 2: Pupils' Interest in Reading Activities after the Reading Workshop

Based on the data gathered in Figure 3, it is apparent that the majority of the participants (61.11\%) agreed that the number of hours allocated for the reading strategy workshop is appropriate. The duration (3-4 hours) for each workshop was properly managed to facilitate the participants as well as give them ample time to fully participate and engage in all of the activities. The report from the field notes also coincides with the parent's point of view via Google Form, as demonstrated in Figure 2.

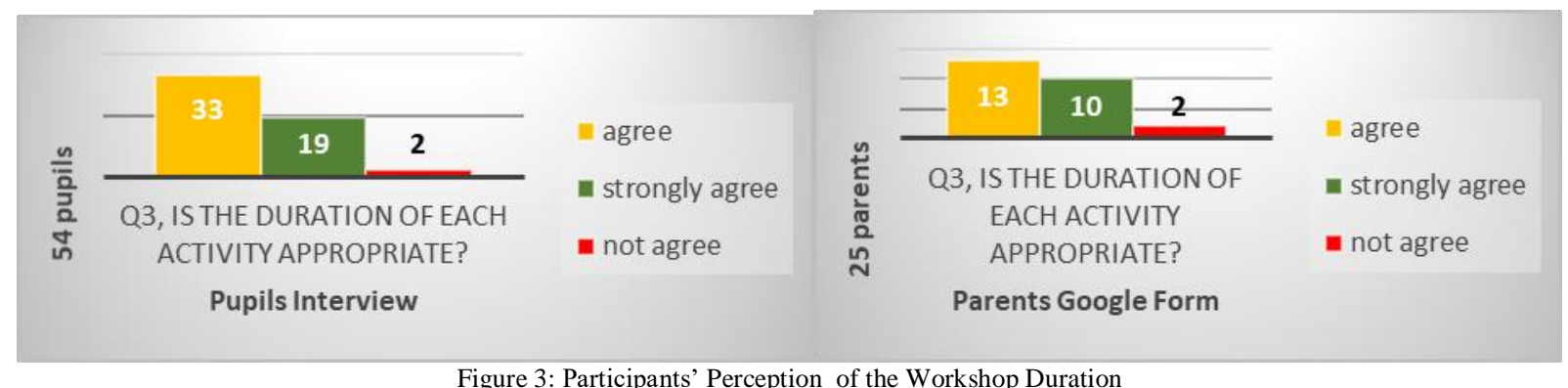

The pupils were also asked about their perceptions about the various activities organized (Are the activities provided able to attract the pupils to read?). Among the questions related to the participants' perception that the researchers posted concerning the participants' future involvement in reading. When they were asked whether they agreed with the statement given in the question (Is the duration of each activity appropriate?), the majority of the participants (43 of them) nodded in agreement. They also mentioned that they would apply the activities that they have learned in the future. On a similar note, the parents' perception also concurred with the statement given by Ling and Hamidah (2020). They believed that the activities could help their children to be immersed in reading English materials. The data is shown in the following Figure 4. 


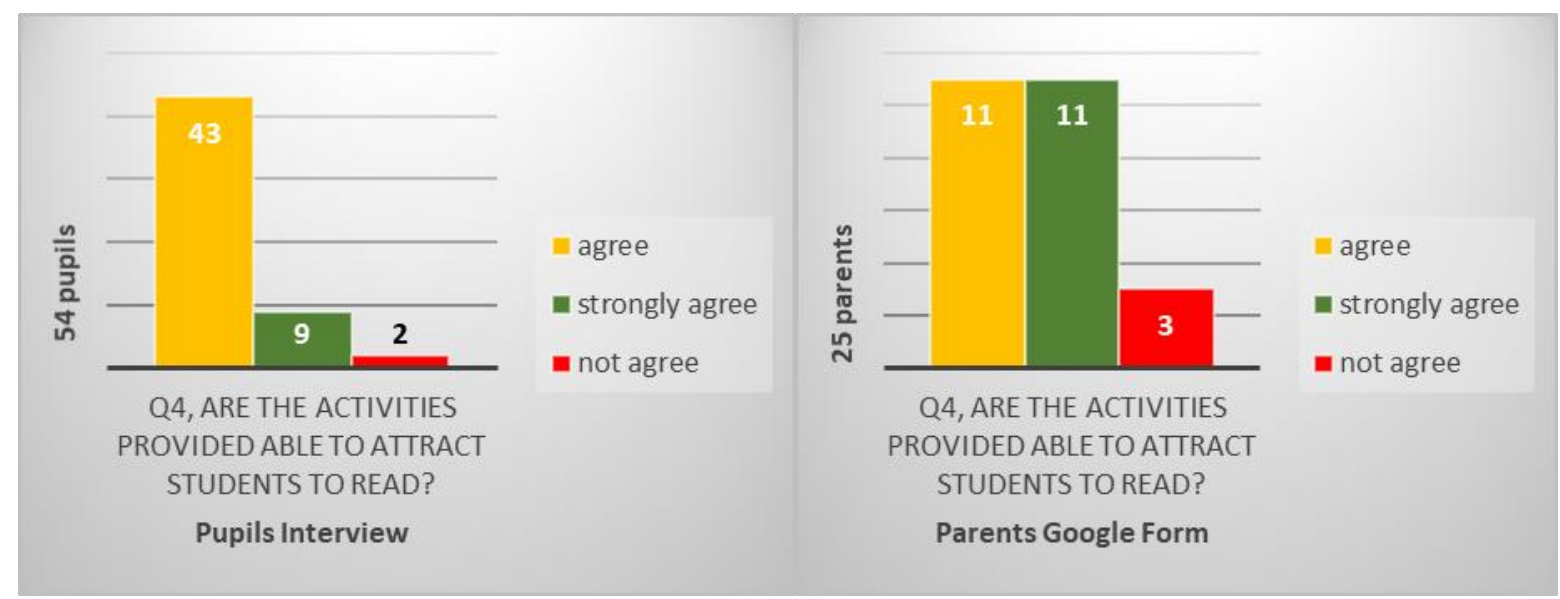

Figure 4: Participants' Responses on the Activities' Ability to Attract the Children to Read

The pupils and parents were asked about their perception of the suitability of the location for the reading workshop conducted. The workshop in Port Dickson was held under a tent in a public event. In Segamat, it was held in the school hall. Lastly, in Jasin, it was held at a resort. Both pupils and parents agreed with the venues of the workshop as shown in Figure 5.

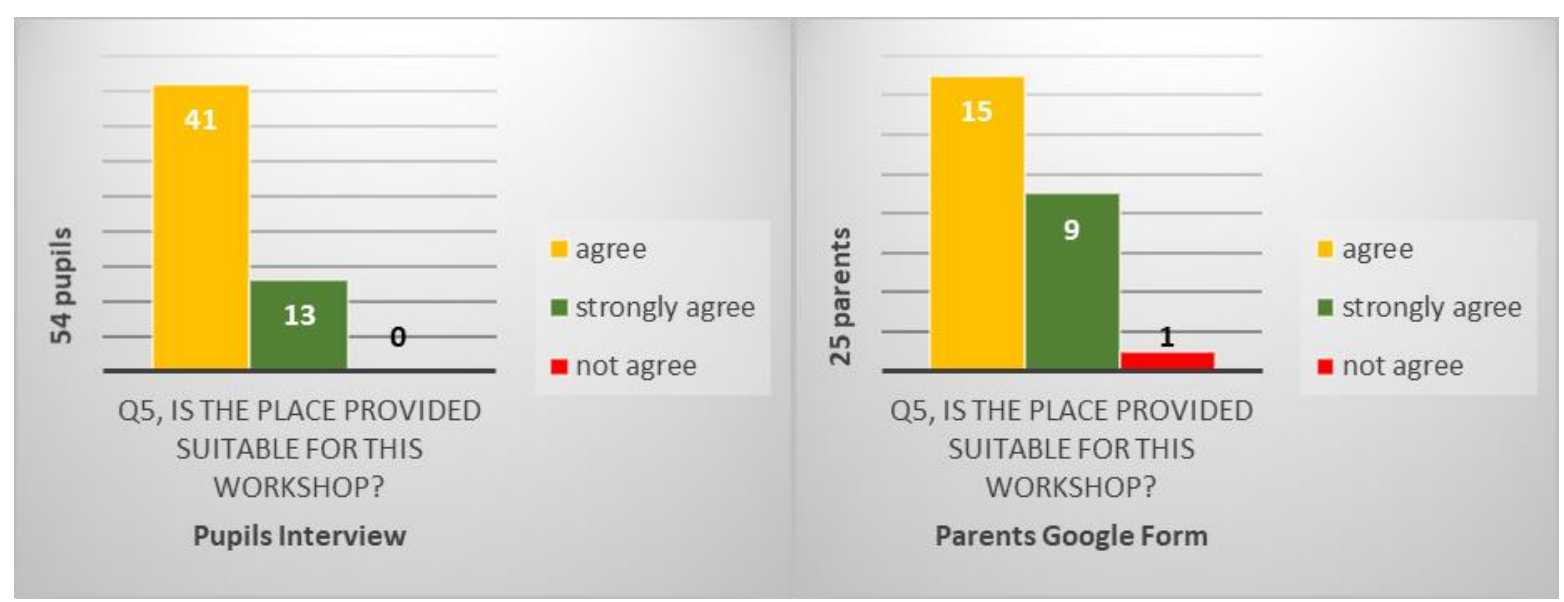

Figure 5: Participants Perception of the Suitability of the Places for the Workshop

The second part of the interview is related to the suggestions in improving the English reading strategy workshop, their responses are similar between the pupils and parents. According to Towle (2000), in order to promote effective reading strategies using mobile phones for each child, the reading workshop should fully utilise the pupils' strengths and needs. This statement is strongly agreed by Lause (2004), in order to promote reading, the activities must promote reading for both pleasure and personal interests. The new knowledge imparted to the pupils should offer the opportunity to pick and choose ebooks from a few of the introduced virtual libraries. One's ability to select and read one's books should be viewed as a necessity especially in Malaysia where English is used widely at many workplaces and many academic references are in English (Ahmad et al., 2020). Literacy and appreciation of literature are pertinent to the pupils' reading, particularly in the ESL context. The pupils are given a list of guided answers and they need to choose the most appropriate answers to enhance and improve the reading strategy workshop that would be conducted in the future. The list was provided to help the participants to answer the given question. 


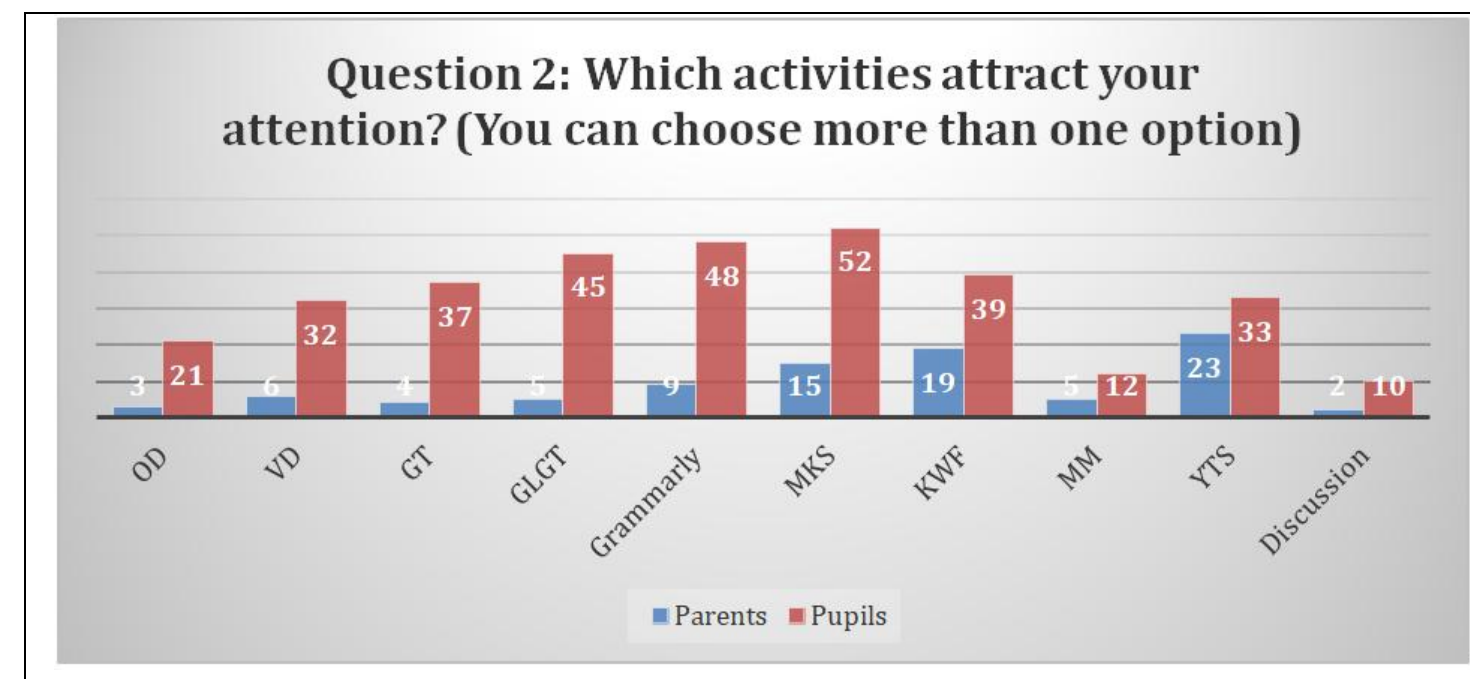

\section{Question 3: How can this workshop be further enhanced in the future?}
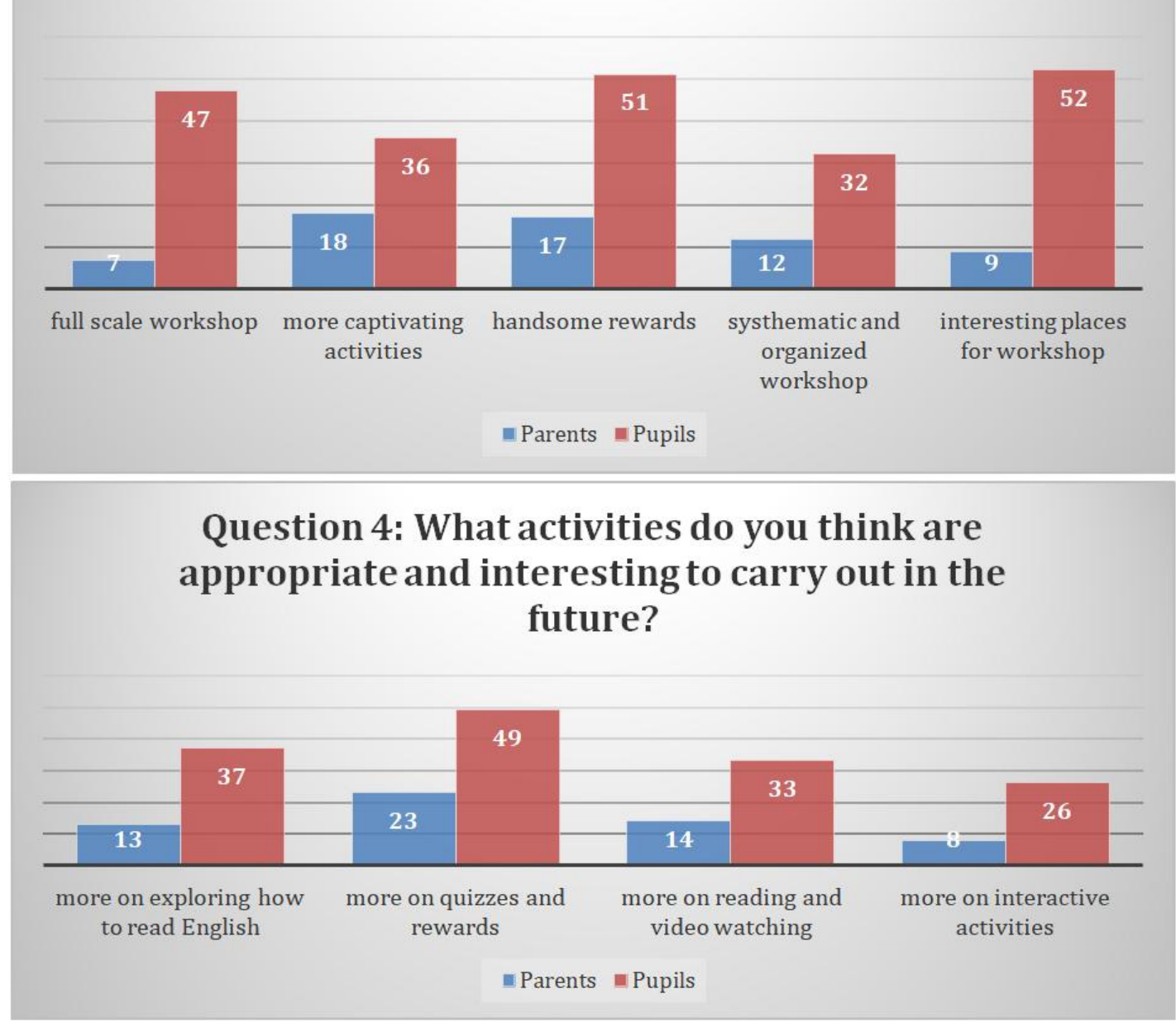

Figure 6: Snapshot of Guided Answer Chosen by Parents and Pupils

"The number of participants in this workshop is suitable and not too many. If the number of participants is too large, I could lose my focus during the workshop" (INT, MLK, PP4)

"In my opinion, the workshop should be promoted to various schools so they can participate in the workshop as well" (INT, MLK, PP8) PP7)

"The organizer should promote this workshop through social media such as Facebook and Instagram" (INT, JHR, 
"Parents are also mesmerized by the applications introduced and eager to help their children in exploring their usage." (FN, NSN, $10 \mathrm{am})$

"Some of the parents require help because the reception of the internet was quite slow in this area." (FN, JHR, 10 am)

"The parents show their ability to use the smartphone with the applications. Parents also helped their children in exploring the apps." (FN, MLK, 3 pm)

b) Research Question 2

This subsection provides the answer to research question 2 - "What are the participants' suggestions to improve the workshop?"

Before the workshop, the researchers had to brainstorm and discuss the possible answers in answering research question 2. So, most of the questions will answer Research Question 2, and it was improvised during the distribution of the open-ended questions via Google Form. Further amendments were also made to the open-ended item based on the interview sessions with other participants during the preliminary study. As a result, suitable and appropriate answers were adapted and written in an open-ended form (refer to the following Figure 7). The participants were instructed to choose and mark their preferred answers from the listed suggestions.

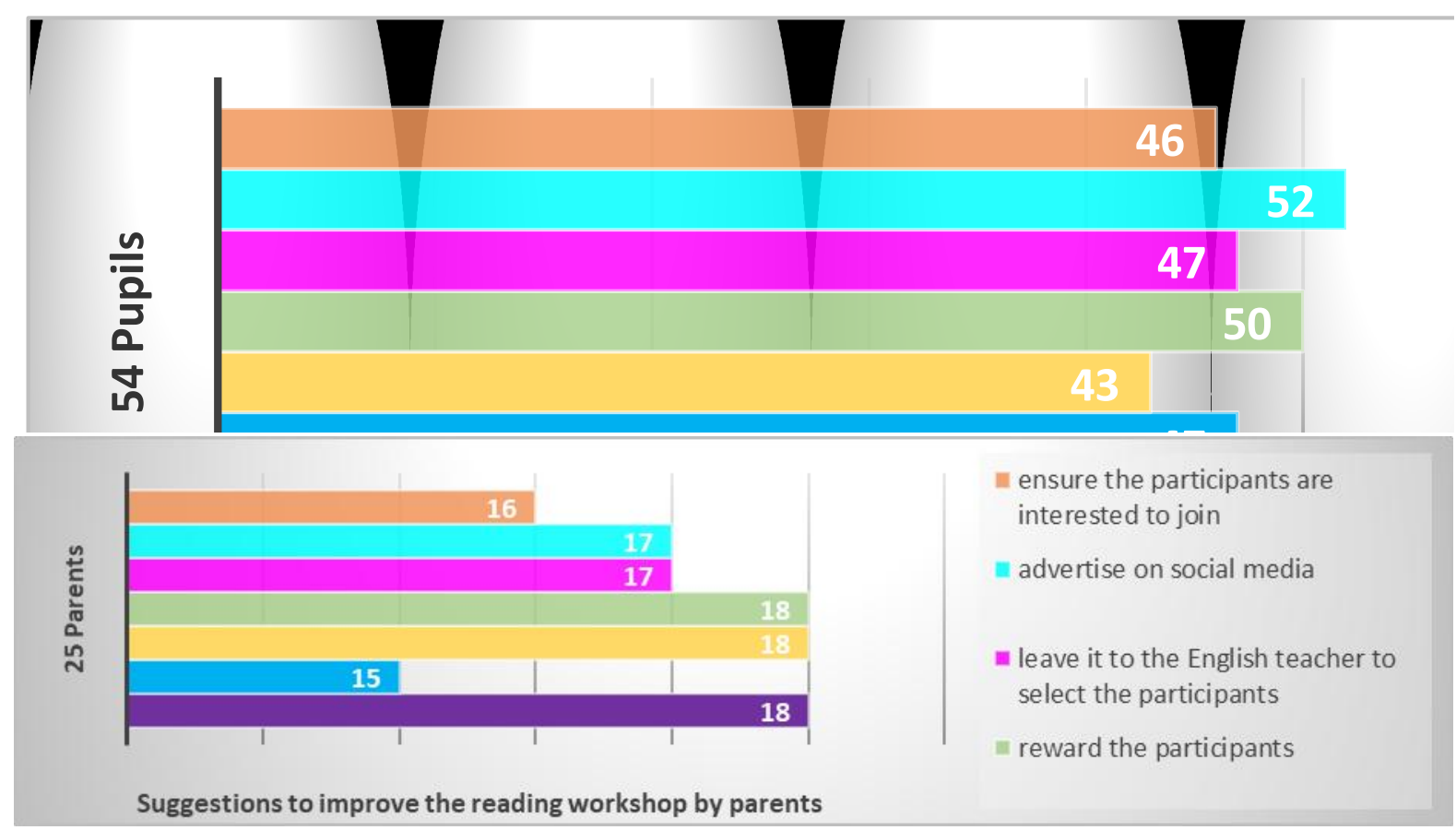

Figure 7: Feedback for Suggestions from the Participants

Figure 7 represents the feedback for suggestions from the participants in regards to improve the reading strategy workshop for future purposes. Despite the numerous suggestions, only suitable and practical ones are to be considered by the researchers. There are five to seven options in each question that they were required to answer (refer to Figure 6). The following suggestions are the most preferred ones marked by the participants. These are amongst the suggestions:

1. Make sure the participants are interested to enrol in the workshop and being actively involved in all the activities.

2. Advertise the reading strategy workshop on all social media platforms to ensure a maximum number of participants can be achieved before the workshop and also enable them to get updated information.

3. The English teachers are responsible for choosing the potential participants as they are familiar with their pupils' capabilities.

4. Reward the participants with suitable items or tokens as a sign of appreciation and to increase their extrinsic motivation.

5. Provide more interactive learning activities on ways to read via mobile applications and smartphones.

6. Provide a certificate of participation for the participants with the university emblem as a sign of appreciation.

7. Provide short quizzes and contests among the participants during the workshop to elevate their interest and promote active learning.

Overall, this reading strategy workshop is a success as the participants expressed their enjoyment throughout the workshop. They proposed the workshop to be carried out in a larger audience due to its benefits to pupils. From the interviews, they agreed that the workshop helps the pupils to improve their English Language proficiency level.

"I can understand more about the gadget and fluently use the English Language" (INT, MLK, PP5) 


\section{"The activities contains edutainment." (INT, MLK, PP3)}

"The usage of smartphone really helps me in mastering the English Language" (INT, MLK, PP11)

Koscik (2020) confirmed that a reading workshop is able to positively change the reading habits among the pupils in $7^{\text {th }}$ grade. Another scholar, York (2020) firmly believed that parents' attitude towards reading is changed after they participate in a reading workshop together with their children.

\section{Discussion}

Based on the findings, it is evident that the reading workshop is effective to improve primary school pupils' reading strategies, reading interests and English proficient level. It is vital for the community to pay attention to an individual's reading strategy to help them become habitual readers (Bartik \& Hershbein, 2018; Samsuddin et al., 2019; Luka and Seniut, 2019). Strategies that could increase students' reading abilities should be introduced to ESL learners to help them improve their reading comprehension level. During the last two decades, significant progress has been made in establishing effective reading practices for children (Williams, 2017; Erdogan, 2019). When it comes to developing and aiding children in their reading development, parental engagement is crucial. Besides, early exposure to parental reading should be encouraged in young children (Lundstrom, 2017; Samsuddin et al., 2019; Gay et al., 2020).

Many of the current pupils' activities are filled with the usage of smartphone applications (Ismail et al., 2016). Hence, this reading workshop which introduced the usage of many apps is deemed to be effective. In addition, the integration of mobile learning in many educational institutions is more common nowadays. Generally, young pupils, particularly those between the age range of 10 to 18 years old, are inclined towards using online games, especially for academic purposes. The findings of this study are parallel with Ismail's findings that with the optimum integration of interactive multimedia and multimedia-capable gadgets, primary school pupils are empowered to read more effectively. If primary school pupils cannot understand their reading materials, they would fall further behind their peers (Erdogan, 2019).

\section{CONCLUSION}

There is an obvious indication that this reading workshop is a success. The participants hope more reading workshops could be carried out on a greater scale of participation from the local community in the future. As reported by the participants, they perceived that the workshop is beneficial and helps the primary school pupils to improve their reading skills in reading English materials.

It is hoped that the local government could provide laptop/iPad/smartphone and internet facilities to underprivileged children for learning purposes. According to the Malaysia Education Blueprint, the government promotes the use of information and communications technologies in teaching and learning activities (Ganapathy, 2016). Nevertheless, poor internet services in rural areas in Malaysia make it difficult for pupils in rural areas to keep abreast with the current developments of language learning (Othman et al., 2019).

\section{ACKNOWLEDGEMENTS}

This research and publication are funded by WakJali Event Management. The grant code is GG-2020-002 and GG . GG-2020-021.

\section{REFERENCES}

[1] Ahmad, Z., Tariq, M., Chaudhry, M. S., \& Ramzan, M. (2020). Parent's role in promoting reading habits among children: an empirical examination. Library Philosophy and Practice, 1-21.

[2] Anstey, M., \& Bull, G. (2018). Foundations of multiliteracies: Reading, writing and talking in the 21 st century. Routledge.

[3] Bartik, T. J., \& Hershbein, B. (2018). Degrees of poverty: The relationship between family income background and the returns to education. https://research.upjohn.org/up_workingpapers/284/

[4] Behtash, E. Z., Barabadi, A., \& Eskandari, Z. (2019). Reading comprehension strategies used by Iranian university students while reading academic English texts. Issues in Educational Research, 29(4), 1089-1106.

[5] Brown, C. L., Schell, R., Denton, R., \& Knode, E. (2019). Family Literacy Coaching: Partnering with Parents for Reading Success. School Community Journal, 29, 63-86.

[6] Chin, C. (2019, Dec, 3). Malaysia Improves in PISA Performance. The Star. https://www.thestar.com.my/news/nation/2019/12/03/malaysia-improves-in-pisa-performance

[7] Cohen, L., Manion, L., \& Morrison, K. (2007). Observation. Research methods in education, 6, 396-412.

[8] Crabtree, B. F., \& Miller, W. L. (1999). Doing qualitative research. Sage.

[9] Daud, R., Jalil, Z. A., \& M. Gunawan, M. N. F. (2015). Community college students' perception towards digital learning In Malaysia. Procedia- Social and Behavioral Sciences, 195, 1798-1802. https://doi.org/10.1016/j.sbspro.2015.06.389.

[10] Driscoll, D. L. (2011). Introduction to primary research: Observations, surveys, and interviews. Writing spaces: Readings on writing, 2, 153-174.

[11] Duff, P. A. (2017). Commentary: Motivation for learning languages other than English in an English-dominant world. The Modern Language Journal, 101(3), 597-607 https://doi.org/10.3991/ijim.v14i02.11819.

[12] Erdoğan, V. (2019). Integrating 4C skills of 21 st century into 4 language skills in EFL classes. International Journal of Education and Research, 7(11), 113-124. 
[13] Fajri, I., Yusuf, R., Maimun, B. A., \& Sanusi, Y. (2020). Innovation model of citizenship education learning in the 21 st-century skill-learning environment of students in Aceh. Innovation, 7(16), 2334 - 2343.

[14] Ganapathy, M. (2016). Transformation of Malaysia's higher education system: Malaysia Education Blueprint (2015-2025). Bulletin of Higher Education Research, 5(1), 10-11.

[15] Brittany, G., Sonnenschein, S., Sun, S., \& Baker, L. (2020). Poverty, Parent Involvement, and Children's Reading Skills: Testing the Compensatory Effect of the Amount of Classroom Reading Instruction. Early Education and Development, DOI, 10(10409289.2020), 1829292.

[16] Gerald, R. (2015). The World beyond the Classroom: 21st Century Education, Technology and 4Cs. https://storify.com/RebeccaG27/4cs-in-education

[17] Govindasamy, P., Yunus, M. M., \& Hashim, H. (2019). Mobile assisted vocabulary learning: Examining the effects on students' vocabulary enhancement. Universal Journal of Educational Research, 7(12), 85-92. https://doi.org/10.13189/ujer.2019.071911.

[18] Hashim, H., Md. Yunus, M., Amin Embi, M., \& Mohamed Ozir, N. A. (2017). Mobile-assisted Language Learning (MALL) for ESL Learners: A Review of affordances and constraints. Sains Humanika, 9(1-5). https://doi.org/10.11113/sh.v9n1-5.1175.

[19] Hasin, I., \& Nasir, M. K. M. (2021). The Effectiveness of the Use of Information and Communication Technology (ICT) in Rural Secondary Schools in Malaysia. Journal of Education and e-Learning Research, 8(1): 59-64. doi:10.20448/journal.509.2021.81.59.64.

[20] Intr, A., \& Ajaj, I. E. (2021). Adapting Technology to Meet 21st-Century Language Learning Difficulties. Journal of Language Studies, 4(3.), 22-31.

[21] Ismail, I., Azizan, S. N., \& Gunasegaran, T. (2016). Mobile learning in Malaysian universities: are students ready? International Journal of Interactive Mobile Technologies, 10(3). 17 - 23.

[22] Klimova, B. (2019). Impact of mobile learning on learners' achievement results. Education Sciences. 9(2). https://doi:10.3390/educsci9020090.

[23] Krashen, S. D. (1988). Second Language Acquisition and Second Language Learning. Prentice-Hall International.

[24] Kung-Teck, W., Muhammad, M., Abdullah, N., \& Hamdan, A. (2020). Mobile-heutagogical practices among student teachers: Its pedagogical affordances and challenges. International Journal of Interactive Mobile Technologies, 14(2), 130-143.

[25] Koscik, D. (2020). The Impact of a Reading Workshop Approach in a Seventh Grade Supplemental Reading Class (Doctoral dissertation, University of South Carolina).

[26] Lause, J. (2004). Using Reading Workshop to Inspire Lifelong Readers. English Journal, 93(5). 23 - 40.

[27] Li, Z., Qiu, Z. (2018). How does family background affect children's educational achievement? Evidence from Contemporary China. J. Chin. Sociol. 5, 13. https://doi.org/10.1186/s40711-018-0083-8.

[28] Ling, C. K. S., \& Yamat, H. (2020). Reading Strategy Use among Good and Poor Primary English as a Second Language Learners. International Journal of Academic Research in Business and Social Sciences, 10, 318-330. https://doi.org/10.6007/IJARBSS/v10-i1/6853.

[29] Luka, I., \& Seniut, I. (2019). Developing students' language competence and essential 21st century skills for future employability: The case of Latvia and Lithuania. Acta Educationis Generalis, 9(2), 1-23.

[30] Lundstrom, S. (2017). The impact of family income on child achievement: Evidence from the Earned Income Tax Credit: Comment. American Economic Review, 107(2), 623-28.

[31] Marshall, M. N. (1996). Sampling for qualitative research. Family practice, 13(6), 522-526.

[32] Masrom, M., Nadzari, A. S., \& Zakaria, S. A. (2016). Implementation of Mobile Learning Apps in Malaysia Higher Education Institutions. In E-Proceeding of the 4th Global Summit on Education (pp. 268-276).

[33] Meikeng, Y. (2019, June 23). Malaysian Love Reading, But Fewer Local Books Sold. The Star, https://www.thestar.com.my/news/nation/2019/06/23/malaysians-love-reading-but-fewer-local-books-sold/.

[34] Mo-Bjørkelund, R. (2020). Readtheory. org-the theory of 21st-century reading: fostering 21st-century reading skills through digital competence, digital teaching aids and frequent digital teaching (Master's thesis, The University of Bergen).

[35] Newman, I., Benz, C. R., \& Ridenour, C. S. (1998). Qualitative-quantitative research methodology: Exploring the interactive continuum. SIU Press.

[36] Niko Sudibjo, Lusiana Idawati, \& HG Retno Harsanti. (2019). Characteristics of learning in the era of Industry 4.0 and Society 5.0. Proceedings of the International Conference on Education Technology (ICoET), September 2019: 276-278.

[37] Othman, B., Harun, A., Ismail, D. A., Sadq, Z. M., Ali, S., \& Ramsey, T. S. (2019). Malaysian consumer behaviour towards internet banking: An application of technology acceptance model. International Journal of Psychosocial Rehabilitation, 23(2), 689-703.

[38] Pellegrino, J. (2017), "Teaching, learning and assessing 21st century skills", in Guerriero, S. (ed.), Pedagogical Knowledge and the Changing Nature of the Teaching Profession, OECD Publishing, Paris, https://doi.org/10.1787/9789264270695-12-en.

[39] Perrin, A. \& Duggan, M. (2015). Americans' Internet access: 2000-2015. Pew Research Center (June 2015): 1-13.

[40] Petscher, Y., Cabell, S. Q., Catts, H. W., Compton, D. L., Foorman, B. R., Hart, S. A., ... \& Wagner, R. K. (2020). How the science of reading informs 21st-century education. Reading research quarterly, 55, S267-S282.

[41] Piaget, Jean (1968). Six Psychological Studies. Anita Tenzer (Trans.), New York: Vintage Books.

[42] Purcell-Gates, V. (2020). Comprehending complexity. In Cultural practices of literacy (pp. 197-216). Routledge.

[43] Rajaram, K. (2021). Evidence-Based Teaching for the 21st Century Classroom and Beyond: Innovation-Driven Learning Strategies. Springer Nature.

[44] Royer, J. S. (1987). A connotational theory of workshop structure (Vol. 273). Springer Science \& Business Media.

[45] Samsuddin, S. F., Shaffril, H. A. M., Bolong, J., \& Mohamed, N. A. (2019). Understanding the reading habit and attitudes among the rural community in low literacy rate areas in Malaysia. Library Management.

[46] Singh, M. K. M., Ying, L. S., \& Muniandy, N. (2021). Taking a Peek at 21st Century Reading. Teaching and Learning of English in the 21st Century: Perspectives and Practices from South East Asia. Penerbit USM. 
https://penerbit.usm.my/index.php/buku/419-teaching-and-learning-of-english-in-the-21st-century-perspectives-and-practicesfrom-south-east-asia

[47] Swift, K. (1993). Try reading workshop in your classroom. The Reading Teacher, 46(5), 366-371.

[48] Talmi, I., Hazzan, O., \& Katz, R. (2018). Intrinsic Motivation and 21st-Century Skills in an Undergraduate Engineering Project: The Formula Student Project. Higher Education Studies, 8(4), 46-58.

[49] Tanaka, M. (2017). Examining EFL vocabulary learning motivation in a demotivating learning environment. System 65: 130138. https://doi:10.1016/j.system.2017.01.010.

[50] Towle, W. (2000). The art of the reading workshop. Educational Leadership, 58(1), 38-41.

[51] White P. J, Marston H. R, Shore L and Turner R. (2020). Learning from COVID-19: Design, Age-friendly Technology, Hacking and Mental Models [version 1; peer review: 1 approved]. Emerald Open Res 2020, 2:21 (https://doi.org/10.35241/emeraldopenres.13599.1)

[52] Williams, M. K. (2017). John Dewey in the 21st century. Journal of Inquiry and Action in Education, 9(1), 7. 91 - 102.

[53] Wong, S. M., Leong, C. M., \& Puah, C. H. (2020). Mobile internet adoption in Malaysian suburbs: The moderating effect of gender. Asian Journal of Business Research, 9(3), 90-114.

[54] Yin, R. K. (2018). Case study research and applications. 5. Sage.

[55] York, C. (2020). Influence of a Shared Reading Workshop on Parent Attitudes Toward Shared Reading (Doctoral dissertation, Middle Tennessee State University).

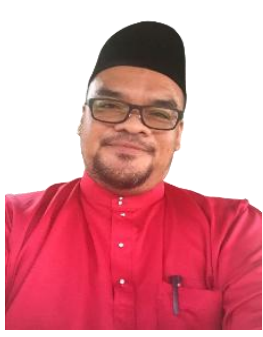

Suher Sulaiman was born in Melaka on December 18th, 1971. The author obtained his Bachelor of Education (Hons) in Teaching of English as a Second Language for Primary Education in a teacher education institution, International Language campus, Malaysia in 2015. Previously he worked as a production operator in one of the factories in Air Keroh, Melaka from 1991 to 1996. He registered himself in a Specialist Teachers' Training College from 1996 to 1999 for a Diploma in TESL. He was posted to Kemaman, Terengganu from 1999 to 2003. He was transferred to Melaka in 2004. He is currently working at a national primary school in Nyalas, Jasin, Melaka while pursuing his Master's part-time. The author has mainly published journal articles online. The author's area of interest includes the integration of technology in English language learning and how it affects pupils' academic performance.

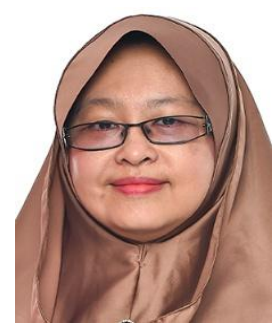

Maslawati Mohamad (Ph.D) was born in Johor, Malaysia. Currently, she is a senior lecturer at the Faculty of Education, Universiti Kebangsaan Malaysia. Her main research interests are innovations in teaching and learning in ESL context, Teaching Reading in ESL context, and English for Specific Purposes. Currently, she has published 101 journal articles including 30 Scopus articles, 55 proceedings, six book chapters and a book. She is also a reviewer for a few international journals and editor for a local journal. She graduated from Universiti Kebangsaan Malaysia and her area of specialization is Teaching English as a Second Language. She had also presented her research output locally and internationally in various seminars and conferences.

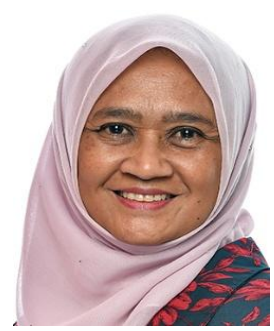

Azlin Norhaini Mansor (Ph.D) begins her career as a teacher in 1987. In 1997 she became an Assistant Director at Educational Planning and Research Division (EPRD), Ministry of Education (MOE) Malaysia, and in 2012, to Universiti Kebangsaan Malaysia (UKM). She is currently a Senior Lecturer at the Centre for Educational Leadership and Policy, Faculty of Education, UKM. She obtained her Bachelor's and Master's degree in Education (Curriculum Planning \& Development) from State University of New York, USA and a doctorate from UKM in Educational Administration. Her areas of expertise include Educational Administration, Leadership, Program Evaluation, Educational Policy Evaluation, Teachers' professionalism, Teaching and Learning, and Research Methodologies. She has published 6 books on leaderships and school management, and various articles on teaching, leadership and management, in a number of journals and proceedings. She is also involved in various research and consultancy projects with other universities, government and nongovernment agencies, including voluntary educational related activities.

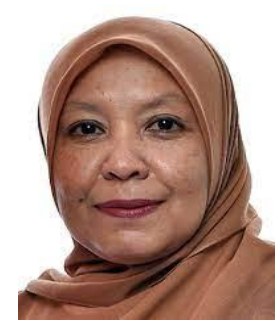

Bity Salwana Alias (Ph.D) is a lecturer at the Center for Educational Leadership and Policy Studies, Faculty of Education, UKM. Holds a PhD and Master's Degree in Educational Administration, Bachelor of Business Administration from International Islamic University, Diploma in International Trade from Sultan Zainal Abidin Religious College and Diploma in Education from Kuala Lumpur Technical College. Started service as a teacher in 1995, then began serving as an Assistant Director in the Ministry of Education Malaysia in 2009 and finally began serving at UKM in 2018. Has expertise in educational administration, management and leadership of educational institutions as well as the development of noble values for harmony, well -being and excellence of the organization. bity@ukm.edu.my. 


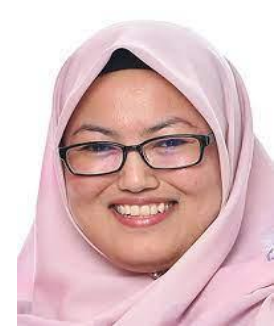

Azlina Abdul Aziz is a TESL lecturer at the Faculty of Education, UKM. She has a Master's degree in English Linguistics, minoring in cross-cultural communication. Her Master's thesis examined the influence of culture in communication among a group of Malaysian Chinese students. She also has an Ed.D in Teaching of English from Teachers College, Columbia University, U.S.A. Her research interests are in the Teaching and Learning of Literature and Teacher Education in TESL. She is interested in how literary texts and personal narrative may be utilised to help students to examine the social, cultural and political issues in a particular context. She has been involved in organising drama workshops as well as personal narrative readings with her TESL undergraduate students. 